\title{
Use of Aluminium Hydroxide Sludge as Adsorbents for the Removal of Reactive Dyes: Equilibrium, Thermodynamic, and Kinetic Studies
}

\section{Burcu Uçar, Afife Güvenç and Ülkü Mehmetoğlu*}

Ankara University, Faculty of Engineering, Chemical Engineering Department, Tandoğan, 06100 Ankara, Turkey

\begin{abstract}
This study investigated the removal of RR-2 and RB-4 dyes from aqueous solutions by adsorption using poppy bagasse, sugar beet bagasse, aluminium hydroxide sludge, phosphogypsum, ferrochromium plant waste, and orange peel. Aluminium hydroxide sludge had the highest adsorption capacity for both dyes. The equilibrium time was 2 days. The effects on adsorption of $\mathrm{pH}$, adsorbent concentration, and stirring rate were investigated. The highest removal percentage was $80.75 \%$ and $99.74 \%$ for RR-2 and RB-4, respectively. Adsorption of RR-2 was expressed better with a Freundlich adsorption equation, while adsorption of RB-4 was expressed better with a Langmuir adsorption equation. Adsorption of RR-2 agreed with the pseudo-first-order rate equation and adsorption of RB-4 followed the pseudo-second-order rate equation. Moreover, both removal processes are endothermic. Various thermodynamic parameters, such as $\Delta \mathrm{G}^{\circ}, \Delta \mathrm{H}^{\circ}$, and $\Delta \mathrm{S}^{\circ}$, were calculated.
\end{abstract}

Keywords: Solid waste; Adsorption; Wastewater; Aluminium hydroxide sludge; Reactive red 2; Reactive Blue 4

Nomenclature: $\mathrm{C}_{\mathrm{A}}$ : Adsorbent concentration (mg/L); $\mathrm{C}_{\mathrm{e}}$ : Equilibrium concentration $(\mathrm{mg} / \mathrm{L}) ; \mathrm{C}_{0}$ : Initial dye concentration $(\mathrm{mg} / \mathrm{L}) ; \mathrm{C}$ : Dye concentration $(\mathrm{mg} / \mathrm{L}) ; \mathrm{k}_{\mathrm{i}}$ : Rate parameter of intraparticle diffusion model (mg dye/g adsorbent min $^{0.5}$ ); $\mathrm{k}_{1}$ : Rate constant of pseudo-firstorder model $\left(\mathrm{min}^{-1}\right) ; \mathrm{k}_{2}$ : Rate constant of pseudo-second-order model, (g adsorbent/mg dye min); K: Langmuir constant (L/mg); $\mathrm{K}_{\mathrm{F}}$ : Freundlich constant $\left((\mathrm{mg} / \mathrm{g})(\mathrm{L} / \mathrm{mg})^{1 / \mathrm{n}}\right) ; \mathrm{n}$ : Freundlich constant; N: Stirring rate $(\mathrm{rpm}) ; \mathrm{q}_{\mathrm{e}}$ : Adsorption capacity in equilibrium (mg dye/g solid); $\mathrm{q}_{\mathrm{e}, \exp }$ : Experimental adsorption capacity in equilibrium (mg dye/g solid); $\mathrm{q}_{\mathrm{e}, \mathrm{cal} .}$ : Calculated adsorption capacity in equilibrium (mg dye/g solid); $\mathrm{q}_{\mathrm{t}}$ : Amount of dye adsorbed onto $1 \mathrm{~g}$ solid at time $\mathrm{t}\left(\mathrm{mg}\right.$ dye/g solid); $\mathrm{Q}^{0}$ : Maximum adsorption capacity (mg dye/g solid); R: Universal gas constant (=8.314 J/mol/K); RB-4: Reactive Blue 4; RR-2: Reactive Red 2; t: Time; T: Temperature; $\Delta \mathrm{G}^{0}$ : Gibbs free energy of adsorption $(\mathrm{kJ} / \mathrm{mol})$; $\Delta \mathrm{H}^{0}$ : Enthalpy change of adsorption (kJ/mol); $\Delta \mathrm{S}^{0}$ : Entropy change of adsorption $(\mathrm{J} / \mathrm{mol} / \mathrm{K})$

\section{Introduction}

Dyes are used in large quantities in many industries including textile, leather, cosmetics, paper, printing, plastic, pharmaceuticals, and food to colour their products [1]. Dyeing in the textile industry uses large amounts of water and generates high volumes of coloured wastewaters. A fair estimation of dye losses to the environment is about $1-2 \%$ during their production and $1-10 \%$ during their use [2].

The remaining dye molecules, even at very low concentrations, in the wastewater of textile industries are common water pollutants. Some dyes are either toxic or mutagenic and carcinogenic due to the presence of metals and other chemicals in their structure. In addition, their presence in water is highly visible and undesirable and may significantly affect photo-synthetic activity in aquatic life due to reduced light penetration $[3,4]$.

Textile dyeing effluents are composed of complex mixtures of dyes, auxiliary chemicals, salts, acids, bases, organochlorinated compounds, and occasionally heavy metals. Colour removal is, however, one of the main problems in the treatment of this kind of effluent, due to dye resistance to biodegradability, light, heat, and oxidizing agents [2]. Considerable research has been done on colour removal from industrial effluents to decrease their impact on the environment. These technologies include adsorption onto inorganic or organic matrices, decolourization by photocatalysis or photo-oxidation processes, microbiological decomposition, chemical oxidation, ozonation, and coagulation [5]. There are many studies in the literature about the removal of Reactive Red 2 and Reactive Blue 4 textile dyes by different methods. Kalyani et al. studied the biodegradation and detoxification of Reactive Red 2 by newly isolated Pseudomonas sp. SUK1. The isolate was able to decolourize sulfonated azo dye (Reactive Red 2) in a wide range $(1-5 \mathrm{~g} / \mathrm{L})$, at a temperature of $30^{\circ} \mathrm{C}$, and $\mathrm{pH}$ range $6.2-7.5$ at 108 $\mathrm{h}$ [6]. Axelsson et al. investigated decolourization of Reactive Red 2 and Reactive Blue 4 using Bjerkandera sp. strain BOL 13 in a batch and a continuous rotating biological contactor reactor [7]. Dye removal efficiency was almost $96 \%$ at the end of 7 days for both dyes $(50 \mathrm{mg} / \mathrm{L})$ in the batch system. Decolourization (80-95\% for [6]; 96\% for [7]) was successful, but the dye removal time (4-5 days for [6]; 7 days for [7]) was very long. Furthermore, Gözmen et al. achieved oxidative degradation of Reactive Blue 4 by different advanced oxidation methods such as wet air oxidation (WAO), wet peroxide oxidation (WPO), photocatalytic oxidation, and electro-fenton (EF) [8]. They found that the most efficient method for the mineralization of Reactive Blue 4 was WPO. Almost complete degradation was achieved in 1-2 minutes by WPO. However, all these techniques are expensive. Bayramoğlu et al. investigated the biosorption of Reactive Blue 4 by native and treated fungus Phanerocheate chrysosporium. The dye uptake capacities of the biosorbents at $600 \mathrm{mg} / \mathrm{L}$ dye concentration were reported to be 132.5, $156.9,147.6$, and $81.1 \mathrm{mg} / \mathrm{g}$ for the native and heat-, acid-, and basetreated dry fungal preparations, respectively [9].

*Corresponding author: Ülkü Mehmetoğlu, Ankara University, Faculty of Engineering, Chemical Engineering Department, Tandoğan, 06100 Ankara, Turkey, Tel: 90-312-203 34 35, Fax: 90-312- 21215 46; E-mail: mehmet@eng. ankara.edu.tr

Received March 03, 2011; Accepted May 10, 2011; Published May 28, 2011

Citation: Uçar B, Güvenç A, Mehmetoğlu Ü (2011) Use of Aluminium Hydroxide Sludge as Adsorbents for the Removal of Reactive Dyes: Equilibrium, Thermodynamic, and Kinetic Studies. Hydrol Current Res 2:112. doi:10.4172/21577587.1000112

Copyright: (C) 2011 Uçar B, et al. This is an open-access article distributed unde the terms of the Creative Commons Attribution License, which permits unrestricted use, distribution, and reproduction in any medium, provided the original author and source are credited. 
The most common process for dye removal is through adsorption by activated carbon; although it is highly effective, running costs are high, with generation required after each sorption cycle [10]. Chitosan is used for this purpose as well. Chiou et al. applied a batch system to study the adsorption of four reactive dyes (RB-2, RR-2, RY-2, and RY86), three acid dyes (AO-12, AR-14, and AO-7), and one direct dye (DR-81) from aqueous solutions by cross-linked chitosan beads [11]. The adsorption capacities for all dyes had very large values of 1911-2498 $\mathrm{mg} / \mathrm{g}$ at $\mathrm{pH} 3-4$ and $30^{\circ} \mathrm{C}$ by cross-linked chitosan beads. However, the acidic treatment ( $\mathrm{pH} \mathrm{3-4)}$ is not suitable environmentally. The utilization of waste materials is increasingly becoming of vital concern because these wastes represent unused resources and, in many cases, present serious disposal problems.

In the literature, many researchers have performed textile wastewater treatment using different solid wastes: waste red mud [12], sugar-industry mud [13], blast furnace dust, sludge, and slag from steel plants and carbon slurry from the fertilizer industry [14], formaldehyde-treated and sulphuric acid-treated sawdust [1], orange peel [15], beer brewery waste [16], sugar beet pulp [4], waste from a soda ash plant [3], and cotton plant waste [17]. Moreover, studies using waste metal hydroxide sludge as potential adsorbents have been reported in the literature. Netpradit et al. found that metal hydroxide sludge (including various insoluble metal hydroxide compounds) is an effective adsorbent for azo reactive dyes (RR-2, RR-120, and RR-141) [18]. Only $0.2 \%(\mathrm{w} / \mathrm{v})$ of powdered sludge $(<75 \mu \mathrm{m})$ achieved colour removal from $30 \mathrm{mg} / \mathrm{L}$ reactive dye solutions (RR-2, RR-120, and RR-141) within 5 min without $\mathrm{pH}$ adjustment. The larger the charge amount of the dyes, the greater the adsorption $(>90 \%)$ on the metal hydroxide sludge. The maximum adsorption capacity for reactive dyes was 42-66 mg dye/g adsorbent $[18,19]$. Santos and Vilar reported that the maximum adsorption capacities varied between $275 \mathrm{mg} / \mathrm{g}$ (at $25^{\circ} \mathrm{C}$ and $\mathrm{pH} 4$ ) and $21.9 \mathrm{mg} / \mathrm{g}$ (at $25^{\circ} \mathrm{C}$ and $\mathrm{pH} 10$ ) for the removal of Remazol Blue reactive dye in aqueous solution by waste metal hydroxide sludge [2].

The aim of the present study was the removal of Reactive Red 2 and Reactive Blue 4 by adsorption from aqueous solutions using poppy bagasse, sugar beet bagasse, aluminium hydroxide sludge, phosphogypsum, ferrochromium plant waste, and orange peel. The adsorption capacity of each solid waste was determined and the solid waste with the maximum adsorption capacity was selected. The effects on adsorption of contact time, initial $\mathrm{pH}$ of solution, initial concentration of adsorbent and stirring rate were investigated. At different temperatures, the Langmuir and Freundlich isotherm models were tested for their applicability. Pseudo-first- and pseudo-secondorder kinetic models were applied to the kinetics of adsorption. Various thermodynamic parameters, such as $\Delta \mathrm{G}^{\circ}, \Delta \mathrm{H}^{\circ}$ and $\Delta \mathrm{S}^{\circ}$, were calculated.

\section{Materials and Methods}

\section{Adsorbents}

Poppy bagasse, sugar beet bagasse, aluminium hydroxide sludge, phosphogypsum, ferrochromium plant waste, and orange peel were used as adsorbents for the removal of Reactive Red 2 and Reactive Blue 4. The wastes were obtained from the Turkish Grain Board Opium Alkaloid Plant (Afyon, Turkey), Afyon Sugar Mill (Afyon, Turkey), Fenis Aluminium Co. Inc. (Kocaeli, Turkey), TUGSAS Samsun Fertilizer Plant (Samsun, Turkey), Eti Chrome Inc. (Elazıg, Turkey), and the Antalya region (Turkey), respectively.

Before drying, the orange peel was ground with a kitchen-type grinder (Moulinex). Then the orange peel, sugar beet bagasse, poppy bagasse, and aluminium hydroxide sludge were dried in an oven at $105^{\circ} \mathrm{C}$ for approximately 8 hours, separately. After drying, the aluminium hydroxide sludge was ground using a mill (Retsch ZM 200). All wastes were sieved and the part of 355-500 $\mu \mathrm{m}$ particle size was used in the experiments.

\section{Dyes}

Reactive Red 2 and Reactive Blue 4 were purchased from SigmaAldrich Co. In the preparation of the dye solutions, distilled water was used. The pHs of dye solutions were adjusted with diluted $\mathrm{H}_{2} \mathrm{SO}_{4}$ and $\mathrm{NaOH}$ solutions.

\section{Sorption studies}

Adsorption experiments: Removal experiments were carried out in $250 \mathrm{~mL}$ screw cap glass bottles with $100 \mathrm{~mL}$ solution volume. Adsorption tests were performed using an orbital shaker (Labcon $5081 \mathrm{U}$ ). Samples were centrifuged at the temperature of $25^{\circ} \mathrm{C}$ and the rate of $4000 \mathrm{rpm}$ for 10 minutes (Hettich Zentrifugen Rotina $35 \mathrm{R}$ ). In the first step of the runs, the effects on adsorption of adsorbent type, contact time (1-5 days), initial $\mathrm{pH}$ of solution $(2,7,10)$, adsorbent concentration $(2,10,20,30 \mathrm{~g} / \mathrm{L})$ and stirring rate $(100,150,200 \mathrm{rpm})$ were investigated at the initial dye concentration of $100 \mathrm{mg} / \mathrm{L}$. Then adsorption isotherms were drawn, kinetic models were tested, and thermodynamic parameters were calculated. from:

The percentage of removal of dye after adsorption was calculated

$$
\text { Removal } \%=\frac{\left(C_{0}-C_{t}\right)}{C_{0}} \times 100
$$

In this equation, $\mathrm{C}_{\mathrm{o}}$ and $\mathrm{C}_{\mathrm{t}}$ are the initial and equation dye concentrations $(\mathrm{mg} / \mathrm{L})$, respectively.

Desorption experiments: The desorption experiments were carried out at the conditions of the temperature of $25^{\circ} \mathrm{C}$, the stirring rate of $150 \mathrm{rpm}$ and the adsorbent concentration of $10 \mathrm{~g} / \mathrm{L}$ through 2 days. from:

The percentage of removal of dye after desorption was calculated

$$
\operatorname{Re} m o v a l \%=\frac{\left(q_{t(\text { afferadsorption })}-q_{q(\text { afferdesorption })}\right)}{q_{t(\text { afferadsorption })}} \times 100
$$

In this equation, $\mathrm{q}_{\mathrm{t}}$, amount of dye adsorbed onto $1 \mathrm{~g}$ solid at time $\mathrm{t}$ (mg dye/g solid)

\section{Analysis}

The concentrations of the dyes in their solutions were determined with a Shimadzu UV 1601 UV spectrophotometer. The wavelengths of maximum absorbance $\left(\lambda_{\max }\right)$ were $536 \mathrm{~nm}$ and $598.5 \mathrm{~nm}$ for RR-2 and RB-4, respectively.

\section{Results and Discussion}

\section{Effect of adsorbent type}

To determine the effects of adsorbent type on adsorption of RR-2 and RB-4, six different solid wastes were used Figure 1. shows changes in the concentration in the dye solutions with contact time. Based on concentration values at the end of $24 \mathrm{~h}$, the solid waste with the highest adsorption capacity was selected. 
Citation: Uçar B, Güvenç A, Mehmetoğlu Ü (2011) Use of Aluminium Hydroxide Sludge as Adsorbents for the Removal of Reactive Dyes: Equilibrium, Thermodynamic, and Kinetic Studies. Hydrol Current Res 2:112. doi:10.4172/2157-7587.1000112

Page 3 of 8

The best adsorption capacity was obtained with aluminium hydroxide sludge for both dyes, i.e. $14.92 \mathrm{mg} / \mathrm{g}$ and $31.80 \mathrm{mg} / \mathrm{g}$ for RR-2 and RB-4, respectively (Table 1). Thus, it was decided to use aluminium hydroxide sludge as the adsorbent in the experiments.

Anionic dyes contain sulfonate ions $\left(\mathrm{SO}_{3}^{-}\right)$[20] and positively charged adsorbents can mostly adsorb these dyes well. Metal hydroxide sludges, which are a waste produced by the electrocoating industry, are suitable adsorbents for textile wastewaters containing anionic dyes. Aluminum hydroxide sludge is a waste that forms by coagulation of aluminium ions in the water used for the anodized coating process in aluminum factories [21-23]. This sludge provides active surfaces for the adsorption of the polluting species such as the textile dyes. During the anodized coating process, the electrolytic dissolution of the aluminum anode produces the cationic monomeric species such as $\mathrm{Al}^{+3}, \mathrm{AlOH}^{+2}$ and $\mathrm{Al}(\mathrm{OH})_{2}{ }^{+}$at low $\mathrm{pH}$. At appropriate $\mathrm{pH}$ values, they are transformed into $\mathrm{Al}(\mathrm{OH})_{3}, \mathrm{Al}(\mathrm{OH})_{4}{ }^{-}, \mathrm{Al}_{2}(\mathrm{OH})_{2}^{+4}$ according to the some hydrolize reactions $[24,25]$. A chemical affinity forms between this positive charge (in aluminum hydroxide sludge) and negative charges in the structures of RR2 and RB4. As a result of this chemical affinity, the resistance of the boundary layer surrounding the adsorbent weakens. Thus, adsorption occurs very easily.

High molecular weight dyes were more strongly adsorbed on the metal hydroxide sludge than the others, because they have a higher negative charge and their solubility is lower than the others [18]. It was observed that the adsorption capacity of RB4 (MW: $637 \mathrm{~g} / \mathrm{mol}$ ) on the aluminium hydroxide sludge was 2-fold higher than that of RR2 (MW: $615 \mathrm{~g} / \mathrm{mol})$.

\section{Effect of contact time}

In this section, the experiments were carried out at the four different adsorbent concentrations over 5 days with sampling every 24 hours. Figure 2. shows the changes in dye removal with contact time. It was observed that there was no remarkable change in dye removal after the second day for all adsorbent concentrations. Therefore, the equilibrium time was accepted as 2 days.
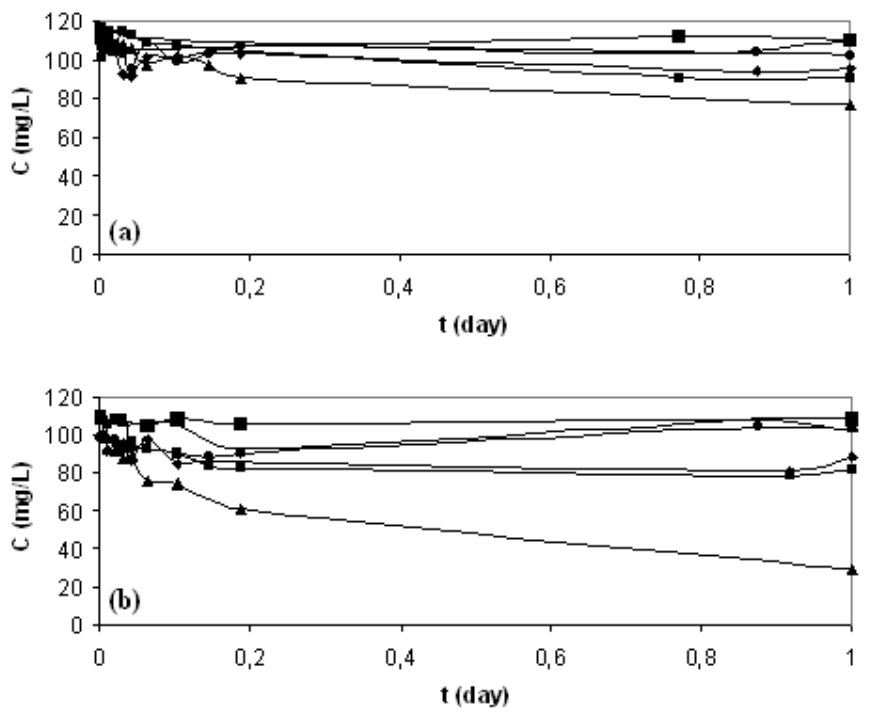

\begin{tabular}{ll}
$\rightarrow-$ Poppy Bagasse & $\rightarrow$ Sugar Beet Bagasse \\
$\rightarrow-$ Phosphogypsum & $\longrightarrow$ - Aumrinium Hydroxide Sudge \\
\hline
\end{tabular}

Figure 1: Effect of adsorbent type on the adsorptions of (a) RR-2 and (b) RB-4 $\left(\mathrm{C}_{0}=100 \mathrm{mg} / \mathrm{L} ; \mathrm{C}_{\mathrm{A}}=2 \mathrm{~g} / \mathrm{L}\right.$; particle size: $355-500 \mu \mathrm{m}$; initial $\mathrm{pH} \sim 7 ; \mathrm{N}=200 \mathrm{rpm}$; $\left.\mathrm{T}=25^{\circ} \mathrm{C}\right)$.

\begin{tabular}{|c|c|c|c|c|}
\hline \multirow{3}{*}{ Adsorbent Type } & \multicolumn{4}{|l|}{ Dye } \\
\hline & \multicolumn{2}{|l|}{ RR-2 } & \multicolumn{2}{|l|}{ RB-4 } \\
\hline & $\begin{array}{l}\mathrm{q}_{\mathrm{t}} \\
\text { (mg dye/g } \\
\text { solid) }\end{array}$ & $\begin{array}{l}\text { Removal } \\
(\%)\end{array}$ & $\begin{array}{l}\mathrm{q}_{\mathrm{t}} \\
\text { (mg dye/g } \\
\text { solid) }\end{array}$ & $\begin{array}{l}\text { Removal } \\
(\%)\end{array}$ \\
\hline Poppy Bagasse & 6.75 & 13.69 & 9.49 & 19.35 \\
\hline Sugar Beet Bagasse & 11.06 & 21.18 & 12.31 & 25.37 \\
\hline $\begin{array}{l}\text { Aluminium Hydroxide } \\
\text { Sludge }\end{array}$ & 14.92 & 30.19 & 31.80 & 70.90 \\
\hline Phosphogypsum & 1.96 & 3.76 & 0.21 & 0.43 \\
\hline $\begin{array}{l}\text { Ferrochromium Plant } \\
\text { Waste }\end{array}$ & 2.47 & 4.68 & 3.13 & 6.45 \\
\hline Orange Peel & 3.98 & 8.08 & 2.50 & 5.16 \\
\hline
\end{tabular}

Table 1: Comparison of removal percentages and adsorption capacities obtained with different solid wastes $\left(C_{0}=100 \mathrm{mg} / \mathrm{L} ; C_{A}=2 \mathrm{~g} / \mathrm{L}\right.$; particle size: $355-500 \mu \mathrm{m}$; initial $\mathrm{pH} \sim 7 ; \mathrm{N}=200 \mathrm{rpm} ; \mathrm{T}=25^{\circ} \mathrm{C}, \mathrm{t}=1$ day).
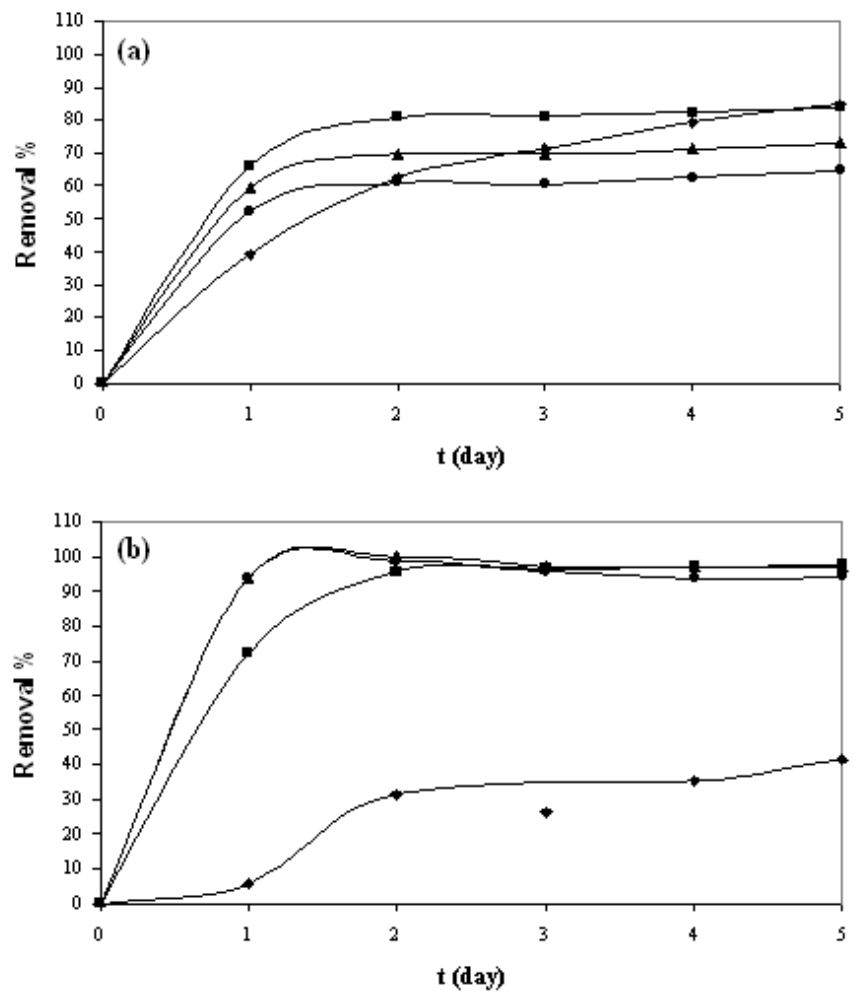

$\rightarrow-\mathrm{CA}=2 \mathrm{gL} \rightarrow-\mathrm{CA}=10 \mathrm{gL} \rightarrow-\mathrm{CA}=20 \mathrm{gL} \rightarrow-\mathrm{CA}=30 \mathrm{gL}$

Figure 2: Effect of contact time on the adsorptions of (a) RR-2 and (b) RB-4 $\left(\mathrm{C}_{0}=100 \mathrm{mg} / \mathrm{L}\right.$; particle size: $355-500 \mu \mathrm{m}$; initial $\mathrm{pH} \sim 7 ; \mathrm{N}=150 \mathrm{rpm} ; \mathrm{T}=25^{\circ} \mathrm{C}$, adsorbent: aluminium hydroxide sludge).

\section{Effect of initial $\mathrm{pH}$}

Three different initial $\mathrm{pH}$ levels were studied, i.e. acidic ( $\mathrm{pH}$ : 2), neutral ( $\mathrm{pH}: 7)$, and basic ( $\mathrm{pH}: 10)$, for both dyes by sampling at particular times over 2 days Figure 3. Shows changes in the dye concentrations with contact time for the three initial $\mathrm{pH}$ levels. The removal percentages achieved at the end of $48 \mathrm{~h}$ are given in Table 2. The maximum removal percentages were $48.37 \%$ and $95.65 \%$ at the $\mathrm{pH}$ of 7 for RR-2 and RB-4, respectively. The difference between the removal percentage of $\mathrm{RB}-4$ for $\mathrm{pH} 7$ and $\mathrm{pH} 10$ is small. Metal hydroxides generally have an amphoteric character. Therefore, the 
adsorption capacity may decrease because of the increasing solubility of the metal hydroxides in the strong acidic or basic medium. The existence of excessive acid or base in the solution decreases the adsorption effectiveness of metal hydroxide sludges [18]. It is thought that the removal operation must be carried out at natural $\mathrm{pH}$.

\section{Effects of adsorbent concentration and stirring rate}

With the aim of investigating the adsorbent concentration and stirring rate effects on removal by adsorption from their aqueous solutions of RR-2 and RB-4, experiments were carried out at four different adsorbent concentrations and three different stirring rates. The removal percentages are shown in Figure 4.

It was found that the maximum removal percentage for RR-2 was $80.75 \%$ at the adsorbent concentration of $10 \mathrm{~g} / \mathrm{L}$ and the stirring rate of $150 \mathrm{rpm}$ (Figure 4). Adsorption of RR-2 increased to a certain value with increasing adsorbent concentration $(10 \mathrm{~g} / \mathrm{L})$. A similar phenomenon was reported in a study that investigated malachite green adsorption on to agro-industry waste [1]. However, the excessive increase reduced the removal percentage to the level obtained at the low adsorbent concentration. This may be attributed to overlapping or aggregation of adsorption sites, resulting in a decrease in total adsorbent surface area available to reactive dyes. The maximum removal percentage for RB-4 was $99.74 \%$ at the adsorbent concentration of $20 \mathrm{~g} / \mathrm{L}$ and the stirring rate of $150 \mathrm{rpm}$ (Figure 4). The increase in adsorbent concentration
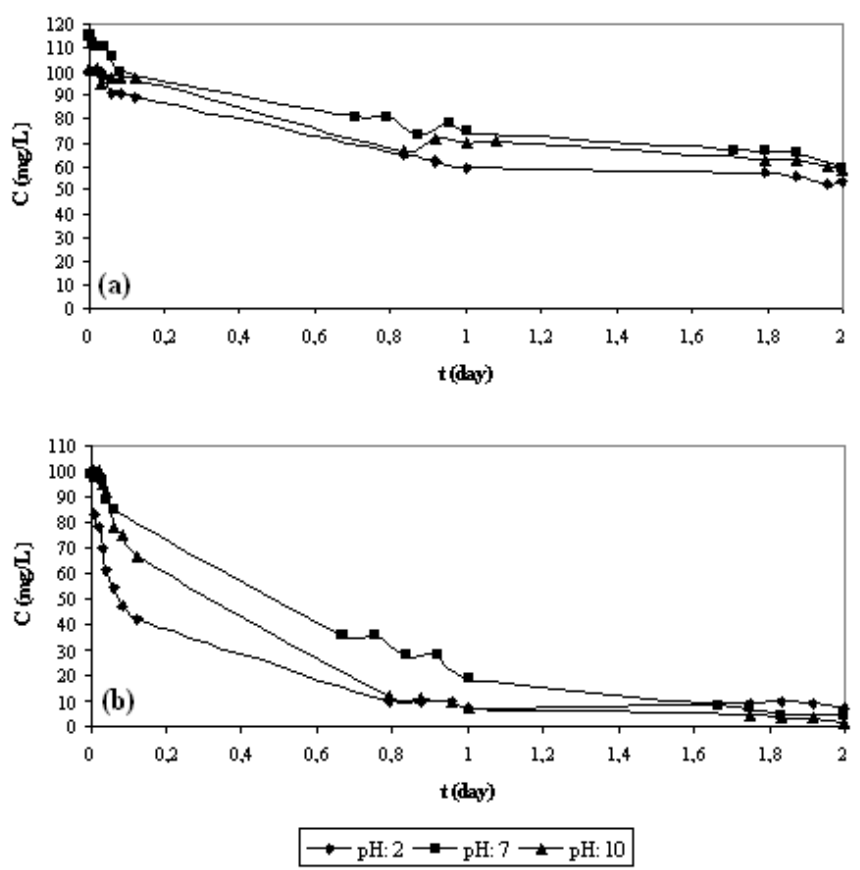

Figure 3: Effect of initial pH on the adsorptions of (a) RR-2 and (b) RB-4. $\left(C_{0}=100 \mathrm{mg} / \mathrm{L} ; C_{A}=20 \mathrm{~g} / \mathrm{L}\right.$; particle size: $355-500 \mu \mathrm{m} ; \mathrm{N}=100 \mathrm{rpm} ; \mathrm{T}=25^{\circ} \mathrm{C}$, adsorbent: aluminium hydroxide sludge).

\begin{tabular}{|l|l|l|}
\hline & \multicolumn{2}{|c|}{ Removal (\%) } \\
\hline $\mathrm{pH}$ & $\mathrm{RR}-2$ & $\mathrm{RB}-4$ \\
\hline 2 & 46.44 & 93.07 \\
\hline 7 & 48.37 & 95.65 \\
\hline 10 & 42.08 & 98.50 \\
\hline
\end{tabular}

Table 2: Effect of initial $\mathrm{pH}\left(\mathrm{C}_{0}=100 \mathrm{mg} / \mathrm{L} ; \mathrm{C}_{\mathrm{A}}=20 \mathrm{~g} / \mathrm{L}\right.$; particle size: $355-500 \mu \mathrm{m}$; $\mathrm{N}=100 \mathrm{rpm} ; \mathrm{T}=25^{\circ} \mathrm{C}$, time: $48 \mathrm{~h}$ ).
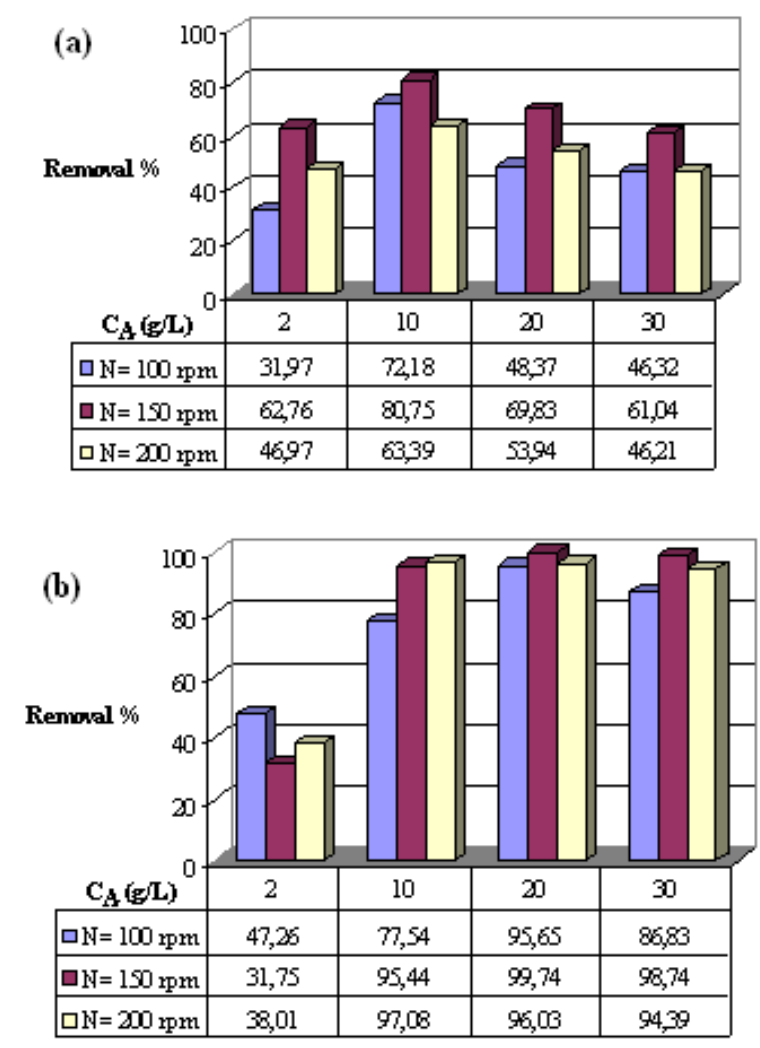

Figure 4: Effect of adsorbent concentration and stirring rate on adsorption of (a) RR-2 and (b) RB-4 dyes. $\left(\mathrm{C}_{0}=100 \mathrm{mg} / \mathrm{L}\right.$; particle size: $355-500 \mu \mathrm{m}$; initial $\mathrm{pH} \mathrm{7}$; $\mathrm{T}=25^{\circ} \mathrm{C}, \mathrm{t}=48 \mathrm{~h}$; adsorbent: aluminium hydroxide sludge).

caused an increase in removal percentage. The mass transfer condition that yielded the highest removal percentage was $150 \mathrm{rpm}$ for both dyes among the examined stirring rates.

\section{Equilibrium of adsorption}

The adsorption isotherms which are the relationships between the amount of dye adsorbed per unit mass of adsorbent $\left(q_{e}\right)$ and the equilibrium concentration $\left(C_{e}\right)$ for RR-2/aluminium hydroxide sludge and RB-4/aluminium hydroxide sludge binary systems at the three temperatures were given in Figure 5(a,b). The experiments were carried out for the five different initial dye concentrations at the temperatures of 25,35 , and $45^{\circ} \mathrm{C}$. Besides the experimental values, the theorical values determined by Langmuir and Freundlich models which are expressed the interaction between adsorbent with dye molecules were also shown in Figure 5(a,b). The Langmuir model is given by Eq. (3).

$$
q_{e}=Q^{0} K C_{e}\left(1+K C_{e}\right)
$$

where $Q^{\circ}$ and $K$ are the Langmuir constants related to maximum adsorption capacity and bonding energy of adsorption, respectively. The Freundlich model is given Eq. (4).

$$
q_{e}=K_{F} C_{e}^{1 / n}
$$

where $K_{F}$ and $n$ are indicators of sorption capacity and sorption intensity which are the Freundlich constants belong to the system, respectively.

As can be seen in Figure 5(a,b), the adsorption capacity increased 
with increasing temperature. This result showed that the process was endothermic. The increase in temperature may cause easy diffusion of the dye to the pores because of increases in the molecule's kinetic energy.

The linear plots of the Langmuir $\left(C / q_{e}\right.$ vs $\left.C_{e}\right)$ and Freundlich $\left(\log q_{e}\right.$ vs $\left.\log C_{e}\right)$ models were given Figure 6(a,b). The maximum adsorption capacities $\left(Q^{\circ}\right)$ and the $K$ constants were calculated from the slope and interception of the Langmuir plots, respectively, by using Equation (5) [18].

$$
\frac{C_{e}}{q_{e}}=\frac{1}{Q^{0} K}+\frac{C_{e}}{Q^{0}}
$$

The Freundlich constants of $\mathrm{n}$ and $\mathrm{K}_{F}$ were calculated from the slope and interception of the Freundlich plots, respectively, by using Equation (6) [18].

$$
\log q_{e}=\log K_{F}+\frac{1}{n} \log C_{e}
$$

Langmuir and Freundlich constants for both dyes at the three temperatures examined are given in Table 3. The Langmuir constants for RR-2 were negative values. Since the mono layer capacity $\left(Q^{\circ}\right)$ and
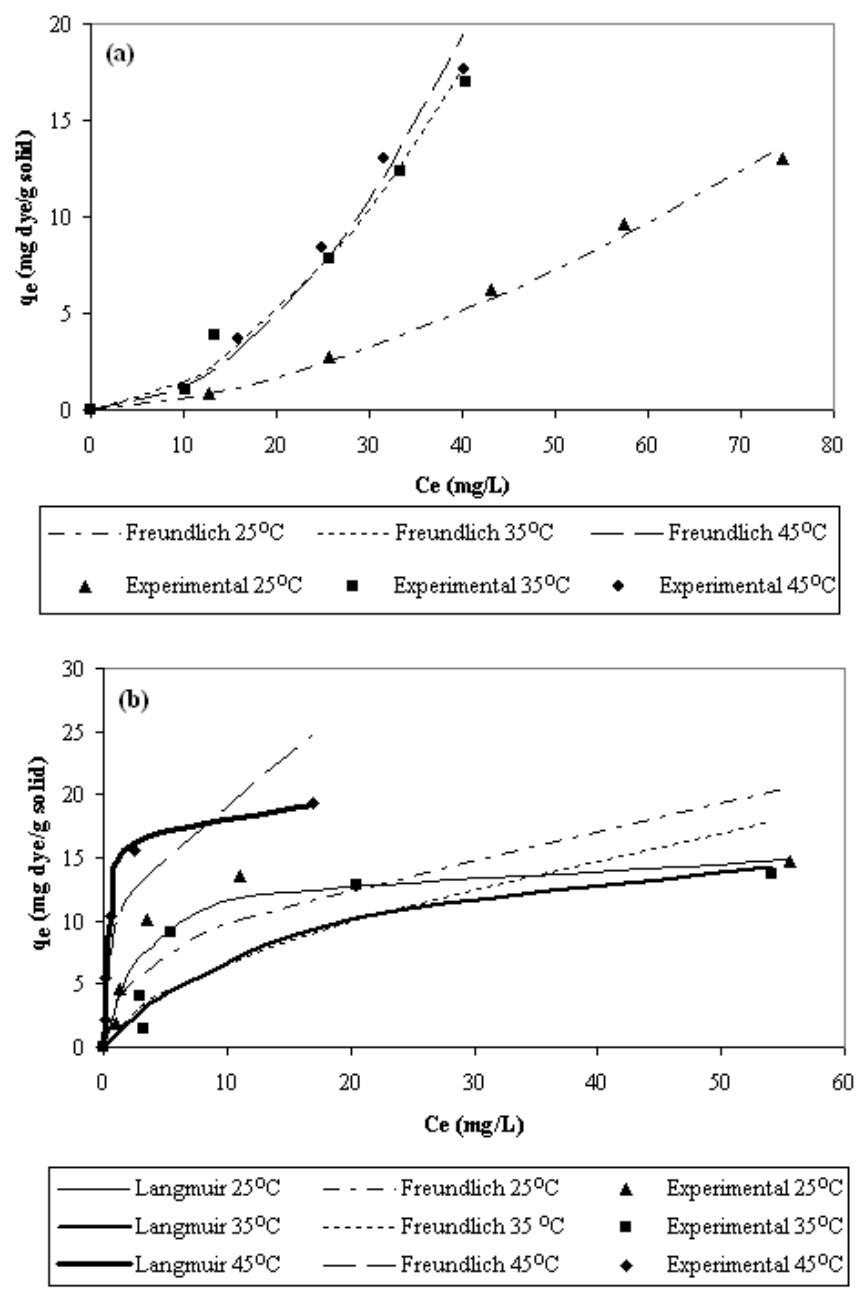

Figure 5: Adsorption isotherms of (a) RR-2 and (b) RB-4. $\left(C_{0}=20 ; 50 ; 100 ; 150\right.$; $200 \mathrm{mg} / \mathrm{L} ; \mathrm{C}_{A}=10 \mathrm{~g} / \mathrm{L}$; particle size: $355-500 \mu \mathrm{m} ; \mathrm{N}=200 \mathrm{rpm}$; initial pH 7; T= $\left.25 ; 35 ; 45^{\circ} \mathrm{C}, \mathrm{t}=48 \mathrm{~h}\right)$.
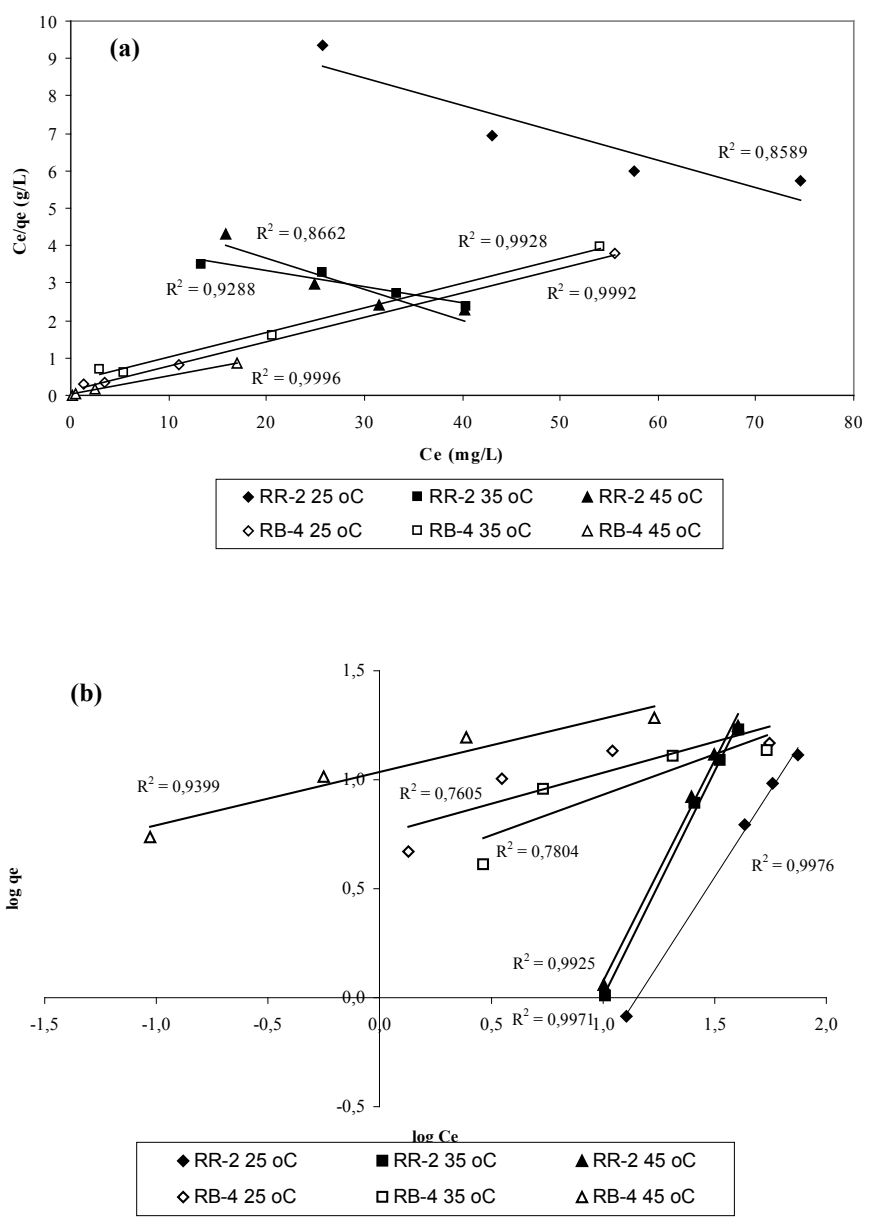

Figure 6: Linear plots of (a) Langmuir model and (b) Freundlich model. $\left(\mathrm{C}_{0}=\right.$ 20; 50; 100; 150; $200 \mathrm{mg} / \mathrm{L} ; \mathrm{C}_{\mathrm{A}}=10 \mathrm{~g} / \mathrm{L} ;$ particle size: $355-500 \mu \mathrm{m} ; \mathrm{N}=200 \mathrm{rpm}$;

\begin{tabular}{|c|c|c|c|c|c|c|c|}
\hline \multirow{2}{*}{ Dye } & \multirow{2}{*}{$\mathrm{T}\left({ }^{\circ} \mathrm{C}\right)$} & \multicolumn{3}{|c|}{ Langmuir Constants } & \multicolumn{3}{|c|}{ Freundlich Constants } \\
\hline & & $\mathrm{Q}^{0}(\mathrm{mg} / \mathrm{g})$ & $\mathrm{K}(\mathrm{L} / \mathrm{mg})$ & $\mathrm{R}^{2}$ & $\mathrm{~K}_{\mathrm{F}}$ & $1 / n$ & $R^{2}$ \\
\hline \multirow{3}{*}{ RR-2 } & 25 & - & - & - & 0.015 & 1.5802 & 0.9970 \\
\hline & 35 & - & - & - & 0.021 & 1.8254 & 0.9308 \\
\hline & 45 & - & - & - & 0.013 & 1.9794 & 0.9871 \\
\hline \multirow{3}{*}{ RB-4 } & 25 & 15.823 & 0.268 & 0.9905 & 3.503 & 0.4418 & 0.7104 \\
\hline & 35 & 18.762 & 0.058 & 0.7183 & 1.712 & 0.5881 & 0.6123 \\
\hline & 45 & 19.881 & 1.809 & 0.9992 & 9.101 & 0.3549 & 0.7742 \\
\hline
\end{tabular}
initial $\mathrm{pH} 7 ; \mathrm{T}=25 ; 35 ; 45^{\circ} \mathrm{C}, \mathrm{t}=48 \mathrm{~h}$ ).

Table 3: Langmuir and Freundlich adsorption isotherm constants for the adsorptions of RR-2 and RB-4 onto aluminium hydroxide sludge $\left(C_{0}=20 ; 50 ; 100\right.$; 150; $200 \mathrm{mg} / \mathrm{L} ; \mathrm{C}_{\mathrm{A}}=10 \mathrm{~g} / \mathrm{L}$; particle size: $355-500 \mu \mathrm{m}$; initial $\mathrm{pH} \mathrm{7;} \mathrm{N=200} \mathrm{rpm;}$ time $=48 \mathrm{~h}$ )

the adsorption equilibrium constant $(K)$ were never negative values, the adsorption isotherms of RR-2/aluminium hydroxide sludge binary system could be said to be inconsistent with the Langmuir adsorption equation. However, they were consistent with the Freundlich adsorption equation by the high regression coefficient. Freundlich isotherms explain the adsorption in heterogeneous surfaces, which are not homogeneous in terms of energy and its functional groups are not specific [3]. The low value of the Freundlich constant $\left(K_{F}\right)$ for RR-2 showed that the capacity of the adsorbent is very sensitive to increase in the dye concentration [18].

The adsorption of RB-4 onto aluminium hydroxide sludge was 
consistent with the Langmuir adsorption equation, but not the Freundlich equation. The Langmuir equation defines the adsorption on strong homogeneous surfaces [3]. Increases in the values of $Q^{0}, K$, and $K_{F}$ with increasing temperature show that the process is endothermic. The value between 0 and 1 of the $1 / n$ constant in the Freundlich equation $(0<(1 / n)<1)$ indicated that the adsorption was suitable [18].

\section{Kinetics of adsorption}

In this section, for the determination of the adsorption kinetics that agreed with the rate equation dye/aluminium hydroxide sludge binary systems and the calculation of adsorption rate constants, experiments were carried out at the adsorbent concentrations of $20 \mathrm{~g} / \mathrm{L}$ by periodically sampling and analysis over 2 days.

$\log \left(q_{e}-q_{t}\right)=\log q_{e}-\frac{k_{1}}{2,303} t \quad$ Pseudo-first-order kinetic model

(Lagergren equation)

$\frac{t}{q_{t}}=\frac{1}{k_{2} q_{e}{ }^{2}}+\frac{t}{q_{e}}$ Pseudo-second-order kinetic model (Ho equation)

The rate constants $k_{1}$ and $q_{e}$ of a pseudo-first-order kinetic model were calculated from the slope and interception of the Lagergren equation [26], respectively, by using Equation. (7) and Figure 7(a).
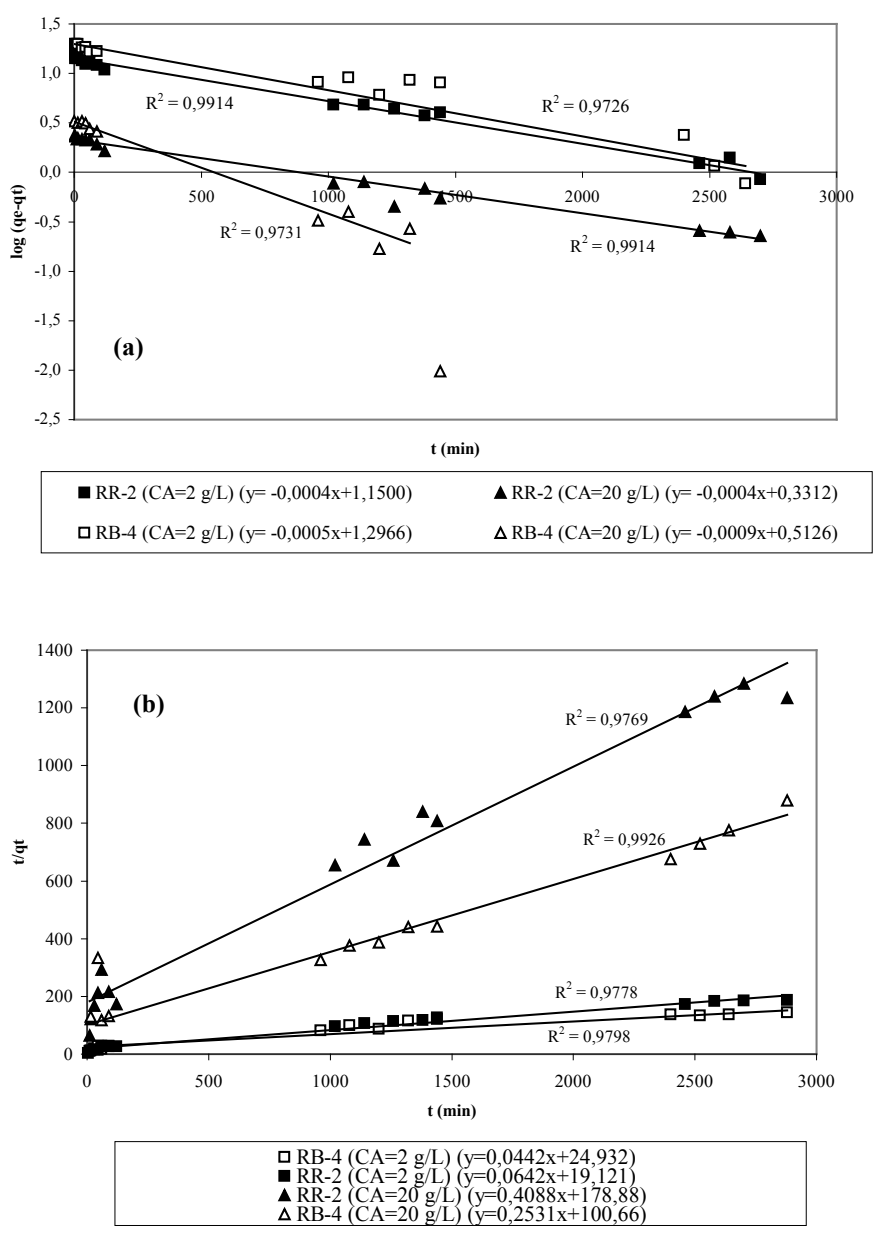

Figure 7: Linear plots of (a) Pseudo-first-order kinetic model and (b) Pseudosecond-order kinetic model. $\left(C_{0}=100 \mathrm{mg} / \mathrm{L} ; C_{A}=2 ; 20 \mathrm{~g} / \mathrm{L}\right.$; particle size: 355 $500 \mu \mathrm{m} ; \mathrm{N}=100 \mathrm{rpm}$; initial $\mathrm{pH} \sim 7 ; \mathrm{T}=25^{\circ} \mathrm{C}, \mathrm{t}=48 \mathrm{~h}$ ).

\begin{tabular}{|l|l|l|l|l|l|l|l|}
\hline & \multicolumn{3}{|c|}{$\begin{array}{l}\text { Pseudo-first-order } \\
\text { kinetic model }\end{array}$} & \multicolumn{5}{c|}{$\begin{array}{l}\text { Pseudo-second-order } \\
\text { kinetic model }\end{array}$} \\
\hline & $\begin{array}{l}\mathrm{q}_{\mathrm{e}, \text { exp }} \\
(\mathrm{mg} / \mathrm{g})\end{array}$ & $\begin{array}{l}\mathrm{k}_{1} \\
\left(\mathrm{~min}^{-1}\right)\end{array}$ & $\begin{array}{l}\mathrm{q}_{\mathrm{e}, \text { cal. }} \\
(\mathrm{mg} / \mathrm{g})\end{array}$ & $\mathrm{R}^{2}$ & $\begin{array}{l}\mathrm{k}_{2} \\
(\mathrm{~g} / \mathrm{mg} / \mathrm{min})\end{array}$ & $\begin{array}{l}\mathrm{q}_{\mathrm{e}, \text { cal. }} \\
(\mathrm{mg} / \mathrm{g})\end{array}$ & $\mathrm{R}^{2}$ \\
\hline RR-2 & 2.33 & 0.0009 & 2.14 & 0.9914 & 0.0009 & 2.45 & 0.9769 \\
\hline RB-4 & 3.27 & 0.0021 & 3.26 & 0.9731 & 0.0006 & 3.95 & 0.9926 \\
\hline
\end{tabular}

Table 4: The rate constants of pseudo-first-order kinetic model and pseudosecond-order kinetic model and correlation constants for RR-2 and RB-4 $\left(C_{0}=100\right.$ $\mathrm{mg} / \mathrm{L} ; \mathrm{C}_{\mathrm{A}}=20 \mathrm{~g} / \mathrm{L}$; particle size: $355-500 \mu \mathrm{m}$; initial $\mathrm{pH} 7 ; \mathrm{N}=100 \mathrm{rpm} ; \mathrm{T}=25^{\circ} \mathrm{C}$, contact time: $48 \mathrm{~h}$ ).

The rate constants $q_{e}$ and $k_{2}$ of a pseudo-second-order kinetic model were calculated from the slope and interception of the Ho equation [27], respectively, by using Equation. (8) and Figure 7(b). The constants obtained for both of dyes are given in Table 4 .

The adsorption of RR-2 on aluminium hydroxide sludge agreed better with the pseudo-first-order kinetic model than the others. It was found that the experimental $\mathrm{q}_{e}$ values were very close to $\mathrm{q}_{e, \text { cal }}$ determined by the pseudo-first-order kinetic model.

The adsorption of RB-4 on aluminium hydroxide sludge agreed better with the pseudo-second-order kinetic model than the others. It was found that the experimental $q_{e}$ values were very close to $q_{e, \text { al }}$ determined by the pseudo-second-order kinetic model.

\section{Thermodynamic parameters}

To determine of the changes in Gibbs free energy $\left(\Delta \mathrm{G}^{0}\right)$, adsorption enthalpy $\left(\Delta \mathrm{H}^{0}\right)$ and adsorption entropy $\left(\Delta \mathrm{S}^{0}\right)$, the following equations $[3,28]$ were used:

$$
\begin{aligned}
& \Delta G^{o}=-R T \ln K \\
& \ln K=-\frac{\Delta H^{0}}{R T}+\frac{\Delta S^{0}}{R} \\
& \Delta H^{o}=\Delta G^{o}+T \Delta S^{o}
\end{aligned}
$$

Since the adsorption of RR-2 on the aluminium hydroxide sludge was not consistent with the Langmuir adsorption equation, the $\mathrm{K}$ constant, which is the Langmuir coefficient related to adsorption energy, was found to be a negative value. For this reason, thermodynamic parameters could not be determined.

For RB-4, firstly, $\mathrm{K}$ values were obtained by the Langmuir adsorption equation at different temperatures. Then $\Delta \mathrm{G}^{0}$ values were determined by putting $\mathrm{K}$ values in Eq. (9). The values of $\Delta \mathrm{H}^{0}$ and $\Delta \mathrm{S}^{0}$ were calculated from the slope and intercept of a Van't Hoff linear plot of $\ln \mathrm{K}$ versus 1/T (Eq.(10)). The results are given in Table 5.

The negative value of $\Delta \mathrm{G}^{0}(-1.567 \mathrm{~kJ} / \mathrm{mol})$ at $45^{\circ} \mathrm{C}$ shows that the adsorption was self-induced at this temperature. The positive values of $\Delta \mathrm{G}^{0}(3.263$ and $7.291 \mathrm{~kJ} / \mathrm{mol})$ at the temperatures of 25 and $35^{\circ} \mathrm{C}$ show that this spontaneousness does not occur at low temperatures. A similar phenomenon was reported in a study that investigated Congo Red adsorption onto activated carbon prepared from coir pith [29]. The fact that $\Delta \mathrm{H}^{0}$ was a positive value $(73.078 \mathrm{~kJ} / \mathrm{mol})$ and higher than 40 $\mathrm{kJ} / \mathrm{mol}$ shows that the adsorption process is chemical and endothermic [30]. Moreover, many researchers have reported that the adsorption of reactive dyes on to different type adsorbents was endothermic $[12,29,31]$. In this state, the bonds formed are very strong. The fact that $\Delta \mathrm{S}^{0}$ was a positive value $(0.228 \mathrm{~J} / \mathrm{mol} / \mathrm{K})$ shows that the disturbance increases at the solid-solvent interface. Similarly, $\Delta S^{0}$ was found to be a positive value $(23.549 \mathrm{~J} / \mathrm{mol} / \mathrm{K})$ in the study mentioned above that investigated Congo Red adsorption [29]. 


\begin{tabular}{|l|l|l|l|l|}
\hline $\mathrm{T}\left({ }^{\circ} \mathrm{C}\right)$ & $\mathrm{K}(\mathrm{L} / \mathrm{mg})$ & $\Delta \mathrm{G}^{\circ}(\mathrm{kJ} / \mathrm{mol})$ & $\Delta \mathrm{H}^{\circ}(\mathrm{kJ} / \mathrm{mol})$ & $\Delta \mathrm{S}^{\circ}(\mathrm{J} / \mathrm{mol} / \mathrm{K})$ \\
\hline 25 & 0.268 & 3.263 & & \\
\hline 35 & 0.058 & 7.291 & 73.078 & 0.228 \\
\hline 45 & 1.809 & -1.567 & & \\
\hline
\end{tabular}

Table 5: Thermodynamic parameters for adsorption of RB-4 onto aluminium hydroxide sludge.

\section{Stability of the dye-adsorbent}

To understand the stability of the dye-adsorbent, the desorption experiments were carried out at the conditions of the temperature of $25^{\circ} \mathrm{C}$, the stirring rate of $150 \mathrm{rpm}$ and the adsorbent concentration of 10 $\mathrm{g} / \mathrm{L}$ through 2 days. In these conditions, desorption yields are obtained $0.56 \%$ and $0 \%$ for RR2 and RB4, respectively. It was found that RR2 and RB4 did hardly ever desorp from the solid. Thus, it could be said that adsorption of RR2 or RB4 onto aluminum hydroxide sludge is chemical adsorption.

\section{Conclusion}

Adsorption of the textile dyes Reactive Red 2 (RR-2) and Reactive Blue 4 (RB-4) onto six different solid wastes was examined. Aluminium hydroxide sludge was the solid waste with the highest adsorption capacity for both dyes. The equilibrium time was two days using aluminium hydroxide sludge for both dyes. For RR-2, the removal percentages were $46.44 \%, 48.37 \%$, and $42.08 \%$ at $\mathrm{pH}$ values of 2,7 , and 10, respectively. For RB-4, the removal percentages were $93.07 \%, 95.65 \%$, and $98.50 \%$ at $\mathrm{pH}$ values of 2,7 , and 10 , respectively. It was decided that the initial $\mathrm{pH}$ mostly did not affect the removal of either dye. When the wastewater is discharged after its treatment, it is important that it is at the natural $\mathrm{pH}$ in terms of protecting the environment. For this reason, the natural $\mathrm{pH}$ was used in this study.

The maximum removal was $80.75 \%$ and $99.74 \%\left(\mathrm{q}_{\mathrm{t}}=7.99 \mathrm{mg} / \mathrm{g}\right.$ and $4.48 \mathrm{mg} / \mathrm{g}$ ) for RR-2 and RB-4, respectively, in the conditions of $\mathrm{C}_{0}=$ $100 \mathrm{mg} / \mathrm{L}$, initial $\mathrm{pH}: 7, \mathrm{~N}=150 \mathrm{rpm}, \mathrm{T}=25^{\circ} \mathrm{C}, \mathrm{t}=2$ days. Aluminium hydroxide sludge is a suitable adsorbent that ensures high removal of both RR-2 and RB-4. It was observed that RB-4 was more adsorbed than RR-2 onto aluminium hydroxide sludge. High molecular weight dyes were more strongly adsorbed on the metal hydroxide sludge than the others.

It was observed that the adsorption capacity increased with increasing temperature $\left(25-45^{\circ} \mathrm{C}\right)$. This shows that the process is endothermic. The adsorption of RR-2 onto aluminium hydroxide sludge is consistent with the Freundlich adsorption equation while the adsorption of RB-4 is consistent with the Langmuir adsorption equation. For the adsorption of RR-2, the dynamic behaviour agrees well with the pseudo-first-order kinetic model. Furthermore, for the adsorption of RB-4, the dynamic behaviour agrees well with the pseudo-second-order kinetic model. The $\mathrm{q}_{\mathrm{e}}$ values calculated by the suitable kinetic model were very close to the experimental $\mathrm{q}_{e}$ values for both dyes. It was observed for RB-4 that the adsorption occurred spontaneously $\left(\Delta \mathrm{G}^{0}=-1.567 \mathrm{~kJ} / \mathrm{mol}\right)$ at high temperature $\left(45^{\circ} \mathrm{C}\right)$ but energy was required $\left(\Delta \mathrm{G}^{0}=3.263 \mathrm{~kJ} / \mathrm{mol}\right.$ at $25^{\circ} \mathrm{C}$ and $7.291 \mathrm{~kJ} / \mathrm{mol}$ at $35^{\circ} \mathrm{C}$ ) for adsorption to occur at low temperature. Moreover, it was seen that the adsorption process is endothermic $\left(\Delta \mathrm{H}^{0}=73.078 \mathrm{~kJ} / \mathrm{mol}\right)$ and chemical $\left(\Delta \mathrm{H}^{0}>40 \mathrm{~kJ} / \mathrm{mol}\right)$. The positive $\Delta \mathrm{S}^{0}$ value $\left(\Delta \mathrm{S}^{0}=0.228\right.$ $\mathrm{J} / \mathrm{mol} / \mathrm{K}$ ) shows that the disturbance increases at the solid-solvent interface.

\section{References}

1. Garg VK, Kumar R, Gupta R (2004) Removal of malachite green dye from aqueous solution by adsorption using agro-industry waste: a case study of Prosopis cineraria. Dyes Pigm 62: 1-10.

2. Santos SCR, Vilar VJP, Boaventura RAR (2008) Waste metal hydroxide sludge as adsorbent for a reactive dye. J Hazard Mater 153: 999-1008.

3. Şener S (2008) Use of solid wastes of the soda ash plant as an adsorbent for the removal of anionic dyes: Equilibrium and kinetic studies. Chem Eng J 138: 207-214.

4. Aksu Z, Isoglu IA (2006) Use of agricultural waste sugar beet pulp for the removal of Gemazol turquoise blue-G reactive dye from aqueous solution. $J$ Hazard Mater 137: 418-430.

5. Isa MH, Lang LS, Asaari FAH, Aziz HA, Ramli NA, et al. (2007) Low cost removal of disperse dyes from aqueous solution using palm ash. Dyes and Pigments 74: 446-453.

6. Kalyani DC, Telke AA, Dhanve RS, Jadhav JP, (2009) Ecofriendly biodegradation and detoxification of Reactive Red 2 textile dye by newly isolated Pseudomonas sp. SUK1. J Hazard Mater 163: 735-742.

7. Axelsson J, Nilsson U, Terrazas E, Aliaga TA, Welander U (2006) Decolorization of the textile dyes Reactive Red 2 and Reactive Blue 4 using Bjerkandera $s p$. Strain BOL 13 in a continuous rotating biological contactor reactor. Enzyme Microb Technol 39: 32-37.

8. Gözmen B, Kayan B, Gizir AM, Hesenov A (2009) Oxidative degradations of reactive blue 4 dye by different advanced oxidation methods. J Hazard Mater 168: 129-136.

9. Bayramoğlu G, Çelik G, Arica MY (2006) Biosorption of Reactive Blue 4 dye by native and treated fungus Phanerocheate chrysosporium: Batch and continuous flow system studies. J Hazard Mater 137: 1689-1697.

10. Robinson T, Cahandran B, Nigam P (2002) Effect of pretreatments of three waste residues, wheat straw, corncobs and barley husks on dye adsorption. Bioresour Technol 85: 119-124.

11. Chiou MS, Ho PY, Li HY (2004) Adsorption of anionic dyes in acid solutions using chemically cross-linked chitosan beads. Dyes Pigm 60: 69-84.

12. Namasivayam C, Arasi DJSE (1997) Removal of congo red from wastewater by adsorption onto waste red mud. Chemosphere 34: 401-417.

13. Magdy YH, Daifullah AAM (1998) Adsorption of a basic dye from aqueous solutions onto sugar-industry-mud in two modes of operations. Waste Manag 18: $219-226$

14. Jain AK, Gupta VK, Bhatnagar A, Suhas (2003) Utilization of industrial waste products as adsorbents for the removal of dyes. J Hazard Mater 101: 31-42.

15. Ardejani FD, Badi K, Limaee NY, Mahmoodi NM, Arami M, et al. (2007) Numerical modelling and laboratory studies on the removal of direct red 23 and direct red 80 dyes from textile effluents using orange peel, a low-cost adsorbent. Dyes Pigm 73: 178-185.

16. Tsai WT, Hsu HC, Su TY, Lin KY, Lin CM (2008) Removal of basic dye (methylene blue) from wastewaters utilizing beer brewery waste. $\mathrm{J}$ Hazard Mater 154 73-78.

17. Tunç Ö, Tanacı H, Aksu Z (2009) Potential use of cotton plant wastes for the removal of Remazol Black B reactive dye. J Hazard Mater 163: 187-198.

18. Netpradit S, Thiravetyan P, Towprayoon S (2004) Adsorption of three azo reactive dyes by metal hydroxide sludge: effect of temperature, $\mathrm{pH}$, and electrolytes. J Colloid Interface Sci 270: 255-261.

19. Netpradit S, Thiravetyan P, Towprayoon S (2003) Application of 'waste' meta hydroxide sludge for adsorption of azo reactive dyes. Water Res 37: 763-772.

20. Akkaya G, Uzun I, Güzel F (2007) Kinetics of the adsorption of reactive dyes by chitin. Dyes Pigm 73: 168-177.

21. Riberio MJ, Tulyaganov DU, Ferreira JMF, Labrincha JA (2004) Production of Al-rich sludge-containing ceramic bodies by different shaping techniques. Mater Process Technol 148: 139-146.

22. Tulyaganov DU, Olhero SMH, Riberio, MJ, Ferreira JMF, Labrincha JA (2002) Mullite-Alumina Refractory Ceramics Obtained from Mixtures of Natural Common Materials and Recycled Al-rich Anodizing Sludge. Journal of Materials Synthesis and Processing 10: 311-318. 
Citation: Uçar B, Güvenç A, Mehmetoğlu Ü (2011) Use of Aluminium Hydroxide Sludge as Adsorbents for the Removal of Reactive Dyes: Equilibrium, Thermodynamic, and Kinetic Studies. Hydrol Current Res 2:112. doi:10.4172/2157-7587.1000112

Page 8 of 8

23. Nepradit S, Thiravetyan $P$, Nakbanpote W, Rattanakajhonsakul K, Tantarawong S, et al. (2004) Waste Metal Hydroxide Sludge as a New Adsorbent. Environ Eng Sci 21: 575-582.

24. Kılıç MG (2009) A parametric comparative study of electrocoagulation and coagulation of aqueous suspensions of kaolinite and quartz powders. PhD Thesis Middle East Technical University Ankara Turkey.

25. Duffty SJ, VanLoon GW (1994) Characterization of Amorphous Aluminum Hydroxide by the Ferron Method. Environ Sci Technol 28: 1950-1956.

26. Lagergren S (1898) Zur theoric dert sogennanten adsorption gelöster stoffe. Handlingar 24: 1-39.

27. Ho YS (1995) Adsorption of heavy metal from waste streams by peat. PhD Thesis University of Birmingham Birmingham.
28. Smith JM,Van Ness HC (1996) Introduction to Chemical Engineering Thermodynamics. Fifth Edition Mc Graw-Hill International Editions New York.

29. Namasivayam C, Kavitha D (2002) Removal of congo red from water by adsorption onto activated carbon prepared from coir pith, an agricultural solid waste. Dyes Pigm 54: 47-58.

30. Koyuncu H, Kul AR, Yıldız N, Çalımlı A, Ceylan H (2007) Equilibrium and kinetic studies for the sorption of 3-methoxybenzaldehyde on activated kaolinites. J Hazard Mater 141: 128-139.

31. Al-Degs YS, El-Barghouthi MI, El-Sheikh AH, Walker GM (2008) Effect of solution $\mathrm{pH}$, ionic strength, and temperature on adsorption behavior of reactive dyes on activated carbon. Dyes Pigm 77: 16-23. 